\title{
HUBUNGAN INDEKS MASSA TUBUH DAN LINGKAR PINGGANG DENGAN TEKANAN DARAH PADA MAHASISWA FAKULTAS KEDOKTERAN UNIVERSITAS SAM RATULANGI
}

\author{
${ }^{1}$ Irene Moudy Sumayku \\ ${ }^{2}$ Karel Pandelaki \\ ${ }^{2}$ M.C.P.Wongkar \\ ${ }^{1}$ Kandidat Skripsi Fakultas Kedokteran Universitas Sam Ratulangi Manado \\ ${ }^{2}$ Bagian Ilmu Penyakit Dalam Fakultas Kedokteran Universitas Sam Ratulangi Manado
}

\begin{abstract}
Weight gain is very influential on the mechanism of the onset oh hypertension in people who are obese. However, this mechanism is not clearly understood but is suspected in people who are obese increased plasma volume and cardiac output will increase blood pressure. The purpose of this study was to determine the relation of body mass index, waist circumference and blood pressure of student in medical faculty of sam ratulangi university. Methods: This study is an analytical type with cross-section. Survey respondents as many as 127 students of the faculty of medicine UNSRAT that met the inclusion criteria. Respondents measured height, weight, waist circumference and blood pressure before the spearmen test. Result: There was a significant correlation between body mass index with systolic and diastolic blood pressure with $\mathrm{p}$ value of 0.001 and $0.004(\mathrm{p}<0.01)$. There was a significant correlation between waist circumference and systolic blood pressure and diastolic pressure with $\mathrm{p}$ values of 0.000 and $0.002(\mathrm{p}<0,01)$. And there also significant correlation between body mass index with waist circumference with a p value of $0.000(\mathrm{p}<0.01)$. Conclusion: The increase in body mass index and waist circumference may affect the blood pressure.
\end{abstract}

Keywords: Body Mass Index,Waist Circumference, Blood Pressure.

\begin{abstract}
Abstrak: Kenaikan berat badan (BB) sangat berpengaruh pada mekanisme timbulnya kejadian hipertensi pada orang yang obes akan tetapi mekanisme terjadinya hal tersebut belum dipahami secara jelas namun diduga pada orang yang obes terjadi peningkatan volume plasma dan curah jantung yang akan meningkatkan tekanan darah.Tujuan penelitian ini untuk mengetahui hubungan indeks massa tubuh dan lingkar pinggang dengan tekanan darah pada mahasiswa Fakultas Kedokteran UNSRAT

Metode: Jenis penelitian ini bersifat analitik dengan pendekatan cross-section.Responden penelitian sebanyak 127 mahasiswa Fakultas Kedokteran UNSRAT yang memenuhi kriteri inklusi. Responden di ukur tinggi badan,berat badan, lingkar pinggang dan tekanan darah. Selanjutnya dilakukan uji Spearmen. Hasil penelitian: Terdapat korelasi yang signifikan antara Indeks Massa Tubuh dengan tekanan darah sistolik dan diastolik dengan nilai $\mathrm{p}$ sebesar 0,001 dan $0,004(\mathrm{p}<0,01)$. Ada hubungan yang signifikan antara lingkar pinggang dengan tekanan darah sistolik dan tekanan darah diastolik dengan nilai $\mathrm{p}$ sebesar 0,000 dan $0,002(\mathrm{p}<0,01)$. Dan terdapat juga hubungan yang signifikan antara indeks massa tubuh dengan lingkar pinggang dengan nilai $p$ sebesar $0,000(p<0,01)$. Simpulan: Peningkatan Indeks Massa Tubuh dan lingkar pinggang dapat berpengaruh kepada tekanan darah.
\end{abstract}

Kata kunci: IMT,Lingkar Pinggang, Tekanan darah.

Masalah kekurangan dan kelebihan gizi pada orang dewasa merupakan masalah penting saat ini karena selain mempunyai faktor resiko penyakit-penyakit tertentu, juga dapat mempengaruhi produktivitas kerja. Oleh karena itu, pemantauan keadaan tersebut perlu dilakukan secara berkesinambungan. Salah satu cara adalah dengan mempertahankan berat badan yang ideal atau normal. ${ }^{1}$

Di Indonesia khususnya, cara pemantauan dan batasan berat badan normal orang 
dewasa belum jelas mengacu pada patokan tertentu. Sejak tahun 1958 digunakan cara perhitungan berat badan normal berdasarkan rumus

$$
\begin{gathered}
\text { Berat badan normal = } \\
\text { (tinggi badan }-100)-10 \% \text { (tinggi badan } \\
-100)
\end{gathered}
$$

Ketentuan ini berlaku umum untuk laki-laki dan perempuan. $^{2}$

Peningkatan Indeks Massa Tubuh (IMT) erat kaitannya dengan penyakit Hipertensi baik pada laki-laki maupun pada perempuan . Kenaikan berat badan (BB) sangat berpengaruh pada mekanisme timbulnya kejadian hipertensi pada orang yang obes akan tetapi mekanisme terjadinya hal tersebut belum dipahami secara jelas namun diduga pada orang yang obes terjadi peningkatan volume plasma dan curah jantung yang akan meningkatkan tekanan darah. Berdasarkan laporan dari Swedish Obese Study di ketahui bahwa angka kejadian hipertensi pada penderita obes sebesar 13,6\%. ${ }^{3}$ Menurut laporan Riskesdas 2007 (Riset Kesehatan Dasar 2007) prevalensi hipertensi di Indonesia sebesar $31,7 \%$. Angka ini cukup tinggi dan bila tidak mendapat pengobatan akan berakhir dengan kematian akibat serangan jantung, stroke dan gagal ginjal. Itu sebabnya penyakit hipertensi sering disebut silent killer. Riskesdas merupakan hasil riset berbasis komunitas dengan sampel rumah tangga dan anggota rumah tangga yang dilaksanakan di 440 kabupaten/kota(dari jumlah keseluruhan sebanyak 454 kabupaten/kota) yang tersebar di 33 provinsi di Indonesia tahun 2007 sehingga data dapat mewakili populasi di tingkat kabupaten/kota di seluruh Indonesia. ${ }^{3}$

\section{METODE PENELITIAN}

Jenis penelitian yang dilakukan adalah bersifat analitik dengan pendekatan cross sectional. Jadwal penelitian dilaksana-kan pada bulan November 2013. Populasi penelitian adalah mahasiswa Fakultas Kedokteran UNSRAT. Sampel penelitian diambil dari populasi sesuai dengan kriteria inklusi: Usia $>18$ tahun, mahasiswa semester 3 Fakultas Kedokteran UNSRAT, bersedia menjadi responden dan menandatangani informed consent.Variabel yang digunakan untuk variabel bebas indeks massa tubuh dan lingkar pinggang dan variabel tergantung adalah tekanan darah. Prosedur penelitian yaitu dilakukan pemilihan mahasiswa yang akan dijadikan sampel.Memberikan penjelasan mengenai cara dan jalannya penelitian. Mahasiswa yang bersedia untuk menjadi responden maka menandatangani formulir persetuju-an informed consent.

Kemudian menyediakan alat dan bahan untuk pemeriksaan alat pengukur tekanan darah,alat pengukur tinggi badan, alat pengukur berat badan, alat pengukur lingkar perut ,stetoskop dan alat tulis menulis Pelaksanaan penelitian responden diukur tinggi badan ,responden diukur berat badan, responden diukur lingkar pinggang, responden diukur tekanan darah.Analisa yang digunakan analisis univariat dilakukan untuk mengetahui distribusi Indeks Massa Tubuh, lingkar pinggang, dan tekanan darah pada mahasiswa Fakultas Kedokteran UNSRAT yang telah diperoleh dari penelitian. Analisis bivariat dilakukan untuk melihat hubungan antara Indeks Massa Tubuh dan tekanan darah pada mahasiswa Fakultas Kedokteran UNSRAT dengan meng-gunakan analisis spearmen. Analisis bivariat dilakukan untuk melihat hubungan antara lingkar pinggang dan tekanan darah pada mahasiswa Fakultas Kedokteran UNSRAT dengan menggunakan juga analisis spearmen.

\section{HASIL PENELITIAN}

Karateristik Umum Sampel Penelitian. Penelitian ini dilaksanakan di Fakultas Kedokteran Universitas SamRatulangi selama satu minggu dari tanggal 4 November 2013 sampai 11 November 2013. Jumlah subjek penelitian yang didapatkan 127 orang, terdiri atas 45 orang laki-laki dan 85 orang perempuan. Usia subjek penelitian dari 19-21 tahun dengan rerata 20 
Sumayku, Pandelaki, Wongkar; Hubungan Indeks Massa Tubuh dan Lingkar Pinggang...

tahun. Indeks Massa Tubuh mulai dari 16$34,1 \mathrm{~cm}$ degan rerata 22,39 cm. Lingkar pinggang mulai dari $55-101 \mathrm{~cm}$ dengan nilai rerata74.06 cm. Tekanan darah sistolik mulai 90-160 mmHg dengan nilai rerata $116.38 \mathrm{mmHg}$. Tekanan darah diastolik 60$100 \mathrm{mmHg}$ dengan nilai rerata 79.15 mmHg. Karakteristik sampel dalam bentuk tabel adalah sebagai berikut.

Tabel 1. Karakteristik umum Sampel Penelitian

\begin{tabular}{lccc}
\hline Variabel & $\mathrm{N}$ & Min-Maks & Rerata \\
\hline Umur & 127 & $19-21$ & 20 \\
JK & & & \\
Perempuan & 82 & & \\
Laki-laki & 45 & & \\
IMT (cm) & 127 & $16-34,1$ & 22,39 \\
LP(cm) & 127 & $55-101$ & 74,06 \\
TDS & 127 & $90-160$ & 116,38 \\
TDD & 127 & $60-100$ & 79.15 \\
\hline
\end{tabular}

Analisa Hubungan Indeks Massa Tubuh dengan Tekanan Darah Berdasarkan penelitian yang dilakukan hasil yang didapatkan adalah nilai korelasi antara IMT dengan tekanan darah sistolik adalah 0,286. Perolehan $\mathrm{p}$ hitung $=0,001<0,01$ yang menandakan bahwa ada hubungan yang signifikan. Sedangkan untuk nilai korelasi antara IMT dengan tekanan darah diastolik adalah 0,252.Perolehan $\mathrm{p}$ hitung = $0,004<0,01$ yang menandakan ada hubungan yang signifikan. Analisa hubungan indeks massa tubuh dengan tekanan darah dalam bentuk tabel sebagai berikut

Tabel 2. Analisa hubungan IMT dengan tekanan darah

\begin{tabular}{|c|c|c|c|c|}
\hline & IMT & \multicolumn{2}{|c|}{ IMT TDS } & TDD \\
\hline $\begin{array}{c}\text { IMT Corelation } \\
\text { coeeficient }\end{array}$ & & 00 & .286 & .252 \\
\hline Sig.(2-tailed) & & & .004 & \\
\hline $\mathrm{N}$ & 127 & 127 & & 127 \\
\hline
\end{tabular}

Analisa Hubungan Lingkar Pinggang dengan Tekanan Darah .Hasil yang didapatkan adalah nilai korelasi lingkar pinggang dengan tekanan darah sistolik adalah 0,311. Perolehan $\mathrm{p}$ hitung $=$ $0,000<0,01$ menandakan ada hubungan yang signifikan.Sedangkan untuk nilai korelasi antara lingkar pinggang dan tekanan darah diastolik adalah 0,272. Perolehan $\mathrm{p}$ hitung $=0,002<0,01$ menan-dakan ada hubungan yang signifikan. Analisa hubungan lingkar pinggang dengan tekanan darah dalam Tabel sebagai berikut:

Tabel 3. Analisa hubungan lingkar pinggang dengan tekanan darah

\begin{tabular}{cccc}
\hline & LP & TDS & TDD \\
\hline LP Correlation & & & \\
Coefficient & 1.000 & .311 & .272 \\
Sig.(2-tailed) & .000 & .002 \\
$\mathrm{~N} \quad 127$ & 127 & 127 \\
\hline
\end{tabular}

Analisa hubungan IMT dengan Lingkar Pinggang .Hasil yang didapatkan adalah nilai korelasi antara IMT dengan lingkar pinggang adalah 0,844. Perolehan p hitung $=0,000$ menandakan ada hubungan yang signifikan. Analisa hubungan IMT dengan lingkar pinggang dalam Tabel sebagai berikut

Tabel 4. Analisa hubungan IMT dengan Lingkar Pinggang

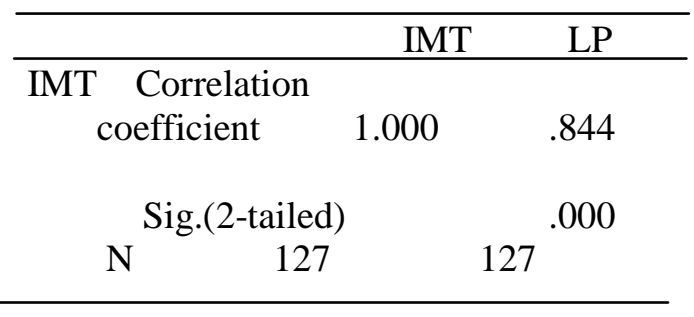

\section{BAHASAN}

Berdasarkan hasil penelitian uji statistik menggunakan uji korelasi Spearmen, Menunjukan bahwa terdapat korelasi yang signifikan antara Indeks Massa Tubuh dengan tekanan darah sistolik dan diastolik dengan nilai $\mathrm{p}$ sebesar 0,001 dan 0,004 $(\mathrm{p}<0,01)$ dengan korelasi koefisien adalah 0,286 dan 0,252. Hasil penelitian ini sejalan dengan hasil pene-litian yang dilakukan oleh Pinzon pada orang-orang yang berusia 1822 tahun yang menunjukan bahwa indeks 
massa tubuh berlebih mempunyai hubungan terhadapa tekanan darah. Begitu juga dengan hasil penelitian yang dilakukan oleh Novianingsih di Semarang pada tahun 2012 yaitu indeks massa tubuh berhu-bungan dengan tekanan darah sistolik dan tekanan darah diastolik. ${ }^{4-5}$

Resiko terkena hipertensi dengan berat badan lebih berpeluang dua sampai tiga kali dibandingkan dengan berat badan yang normal atau kurus. Demikian juga dengan penelitian Liu di China menunjukan bahwa responden obesitas mempunyai resiko 3,9 kali lebih tinggi menjadi hipertensi dibandingkan dengan responden yang memiliki indeks massa tubuh kurang dari 25 $\mathrm{kg} / \mathrm{m}^{2 .}$.

Berdasarkan hasil uji statistik menggunakan uji korelasi spearmen, menunjukan bahwa ada hubungan yang signifikan antara lingkar pinggang dengan tekanan darah sistolik dan tekanan darah diastolik dengan nilai $\mathrm{p}$ sebesar 0,000 dan 0,002 ( $<<0,01$ ), dan angka koefisien korelasi yaitu 0,311 dan 0,272 . Hal ini sesuai dengan banyaknya penelitian yang menyatakan ada hubungan yang bermakna antara lingkar pinggang dengan tekanan darah, karena pada studi prospektif menunjukan bahwa lingkar pinggang berhubungan erat dengan penyakit kardiovaskuler. ${ }^{1}$ Hal ini sejalan dengan penelitian yang dilakukan oleh The National Heart, Lung and Blood Institute tahun 2005 meng-hasilkan data bahwa pasien dengan tekanan darah tinggi lebih banyak di temukan pada orang yang obesitas sentral. Banyaknya penumpukan lemak disekitar abdomen sering berhu-bungan signifikan dengan tekanan darah. Pengukuran lingkar pinggang merupakan teknik antropometri yang paling baik untuk menentukan timbunan lemak disekitar abdomen atau yang disebut sebagai obesitas sentral. Responden dengan berat badan lebih akan terjadi penumpukan jaringan lemak, yang dapat menyebabkan peningkatan resistensi pembuluh darah dalam meningkatkan kerja jantung untuk memompakan darah keseluruh tubuh. ${ }^{8}$

Berdasarkan hasil uji statistik menggunakan uji korelasi spearmen,menunjukan bahwa ada hubungan yang signifikan antara indeks massa tubuh dengan lingkar pinggang dengan nilai $p$ sebesar 0,000 $(\mathrm{p}<0,01)$ dan angka koefisien korelasi yaitu 0,844 .

Indeks massa tubuh berhubungan erat dengan derajat jaringan lemak. Untuk menilai derajat jaringan lemak dapat dilakukan pengukuran lingkar pinggang karena pengumpulan lemak ada di sekitar panggul dan pinggang. ${ }^{9}$

Walaupun IMT $<25 \mathrm{~kg} / \mathrm{m}^{2}$, obesitas sentral dapat saja terjadi sehingga penyesuaian indeks massa tubuh pada keadaan obesitas sentral sangat diper-hatikan, terutama indeks massa tubuh diantara 22-29 $\mathrm{kg} / \mathrm{m}^{2}$. Lingkar pinggang dikatakan mempunyai korelasi yang tinggi dengan jumlah lemak intraabdominal. Jaringan lemak intrabdominal terdiri dari lemak viseral atau lemak intraperitoneal yang terdiri dari lemak omental dan mesenterial serta masa lemak retro-peritoneal. Lingkar pinggang berkorelasi baik dengan indeks massa tubuh baik laki-laki maupun perempuan dengan $r=0,089$ dengann $\mathrm{p}<0,01^{9}$

\section{DAFTAR PUSTAKA}

1. Supariasa I, Bakri B, Fajar I. Penilaian status gizi. Jakarta: Buku kedokteran EGC, 2012. Hal 59-60

2. Yogiantoro M. Hipertensi esensial. Dalam:Sudoyo A, Setiyohadi B, Alwi I, Simadibrata M, Setiati S, editor. Buku ajar ilmu penyakit dalam Jilid 3, Edisi 5.2009. Hal 1079

3. Sihombing M. Hubungan perilaku merokok konsumsi makanan/minuman dan aktivitas fisik dengan penyakit hipertensi. Majalah kedokteran Indonesia, Volume 60,2010.

4. Pinzon R. Indeks Massa Tubuh sebagai Faktor Risiko hipertensi pada Usia Muda. Cermin Dunia Kedokteran 1999,123:9-11

5. Novianingsih, Eva dan Apoina Kartini.2012. Hubungan Antara Beberapa Indikator Status Gizi Dengan Tekanan Darah Pada Remaja. Program Studi Ilmu Gizi Fakultas Kedokteran Universitas Diponegoro.Semarang

6. Liu L,Ikeda K, Chen M, Yin W, Mizushima S, Miki T. Obesity,emerging risk in China: trend of increasing prevalence of obesity 
Sumayku, Pandelaki, Wongkar; Hubungan Indeks Massa Tubuh dan Lingkar Pinggang...

and its association with hypertension and hypercholestrolaemia among the Chinese. Clin Exp Pharmacol Physiol. 2004,31:8-10

7. Gibson, Rosalind S.2005. Principles of nutrition Assesment.New York

8. Schmieder, RE, Messerli,FH. Does influence early target organ damage in hypertensive

circulation.1993;87:1482

patients

9. Sugondo S. Obesitas. Dalam:Sudoyo A, Setiyohadi B, Alwi I, Simadibrata M, Setiati S, editor. Buku ajar ilmu penyakit dalam Jilid 3, Edisi 5.2009. Hal 1977-1980 